\title{
SISTEM PEMBELAJARAN DI PONDOK PESANTREN AL-AZIZIYAH ANALISIS TERHADAP METODE DALAM KEGIATAN PEMBELAJARAN FORMAL DAN NONFORMAL
}

\author{
H. M. Natsir \\ Fakultas Tarbiyah dan Keguruan Universitas Islam Negeri Mataram \\ E-mail: hmuh.nasir@gmail.com
}

\begin{abstract}
Abstrak: tujuan penelitian ini adalah mengetahui metode-metode, Langkah penerapan metode, faktor pendukung dan penghambat serta Langkah antisipasi pada pembelajaran formal dan non formal di Pondok Pesantren Al-Aziziyah Kapek Gunungsari Lombok Barat. Pendekatan yang digunakan peneliti dalam penelitian ini adalah pendekatan deskriptif kualitatif. Sebab orientasi penelitian yang dilakukan berdasarkan pada gejala atau fenomena yang bersifat alam. Analisis yang digunakan menggunakan model Mills Hubberman (1) data Reduction (Reduksi Data) yang berarti merangkum, memilih hal-hal yang pokok, memfokuskan pada hal-hal yang penting, dicari tema dan pokoknya dan membuang yang tidak perlu.(2) data Display (Penyajian Data) yang bentuknya bisa uraian singkat, bagan, hubungan antar kategori dansejenisnya, (3) Conclusion Drawing atau Verification (Mengambil Kesimpulan dan Verifikasi). Hasil penelitian menunjukkan bahwa beberapa metode dapat diterapkan oleh ustadz/ustadzah dalam kegiatan pembelajaran tuntutan kemampuan dan keterampilan guru dalam menerapkan metode yang relevan dengan tujuan menjadi suatu keharusan baik di kelas non formal terebih di kelas formal. Adanya perbedaan penerapan jenis metode pembelajaran disebabkan karena tujuan pembelajaran yang berbeda, berarti tuntutan untuk mengetahui jenis-jenis metode dan keterampilan dalam terpannya secara terpadu menjadi suatu keharusan, yang keberhasilannya diperoleh melalui penerapan jenis alat evaluasi yang juga searah dengan tujuan pembelajaran yang dicapai.
\end{abstract}

Kata Kunci: Metode, Pembelajaran, Kelas Formal dan Nonformal, Ponpes Al-Aziziyah

Title: Learning System In Al-Azirizab Boarding School:Applied Analysis Methods In Activities Formal And Non Formal Learning

Abstrak. The purpose of this study was to find out the methods applied, the steps of applying the methods, factors that support, binder and anticipatory steps in overcoming the inbibiting factors the application of methods to formal and non-formal learning in Al-Airizivah Boarding School Kapek Gunungsari West Lombok. The approach used by researchers in this study is a qualitative descriptive approach. Because the orientation of the research carried out is based on symptoms or phenomena that are of a nature nature. The analysis used uses the Mills Hubberman model (1) Data Reduction, which means summarizing, choosing the main points, focusing on the important things, looking for themes and points and removing unnecessary. (2) Display data (Presentation of Data) whose form can be brief description, chart, relationships between categories and types, (3) Conclusion Drawing or Verification (Taking Conclusions and Verifications) The results of the study indicate that a number of methods can be applied by teachers or religious teachers / ustadzah in to formal and non-formal learning. The demand for the ability and skills of teachers to apply methods that are relevant to the objectives becomes a necessity both in non-formal classes especially in formal classes. The difference in the application of this type of learning method is due to different learning objectives, This means that the demand to know the types of methods and skills in their integrated integration becomes a necessity, the success of which is obtained through the application of evaluation tools that are also in line with the learning objectives achieved.

Keywords: Method, Learning, Formal and Non-formal Classes, Al-Aziriyah Islamic Boarding School 


\section{PENDAHULUAN}

Kesadaran masyarakat akan pentingnya pendidikan bagi pemenuhan kebutuhan pengetahuan dan pembinaan sikap serta keterampilan dalam berbagai aspek kehidupan menjadi landasan pijakan berpikir tokoh-tokoh masyarakat dalam mempersiapkan lembagalembaga pendidikan untuk memenuhi kebutuh an tersebut di samping konsep secara nasional dan bahkan internasional dalam rangka membantu pemerintah mencerdasakan kehidupan bangsa agar dapat sejajar dalam kehidupan masyarakat internasional.

Paradigma berfikir tokoh masyarakat yang bertujuan membantu pemerintah menjejajarkan kehidupan masyarakat dalam konteks berbangsa dan bernegara sehingga dapat disandingkan dalam kehidupan internasional atau setara dengan kehidupan dan tingkat berpikir di negara lain diwujudkan dalam bentuk nyata dengan didirikannya lembaga-lembaga pendidikan Islam atau madrasah yang bernaung di bawah yayasan atau pondok pesantren dengan sistem pembelajaran formal dan non formal.

Diakui bersama pada awalnya pondok pesantren khususnya dalam konteks pembelajaran menggunakan pendekatan holistik dimana "para pengasuh pesantren memandang bahwa kegiatan belajar-mengajar (baca pembelajaran) merupakan kesatupaduan atau lebur dalam totalitas kegiatan hidup sehari-hari, sehingga bagi warga pesantren belajar tidak mengenal perhitungan waktu, kapan harus dimulai dan harus selesai, dan target apa yang harus dicapai. Warga pesantren sama mengaku bahwa ilmu agma fardu ain dipandang sakral sedangkan ilmu umum fardu kifayah tidak sakral "1

Mencermati sarana pendukung pelaksanaan pembelajaran di awal berdirinya pondok pesantren masih sangat-sangat terbatas, sebab sarana pembelajaran yang digunakan dalam kegiatan pembelajaran kitab kuning hanya memanfaatkan masjid dan rumah kyai, ini sesuai dengan elemen dari pondok pesantren itu sendiri adalah "kyai, pondok, santri, masjid, pembelajaran kitab kuning"'2. Pembelajaran kitab kuning atau kitab-kitab wajib (Kutubul Muqarrarab) di pondok pesantren dimaksudkan agar para santri benar-benar ahli dalam bidang agama dan ilmu pengetahuan kemasyarakat serta berakhlak mulia, ini sesuai dengan tujuan pesantren sebagai lembaga pendidikan Islam yaitu "menjadikan para santri sebagai manusia yang mandiri yang diharapkan dapat menjadi pemimpin umat dalam menuju keridlaan Tuhan". 3

${ }^{1}$ Mastuhu, Dinamika Sistem Pendidikan Pesantren: Suatu Kajian Tentang Unsur dan Nilai Sistem Pendidikan Pesantren, (Jakarta : Indonesia-Netherlands Cooperation in Islamic Studies/INIS, 1994), h. 58

${ }^{2}$ Tafsir, Ahmad, Ilmu Pendidikan dalam Perspektif Islam, (Bandung : Remaja Rosdakarya, 1992), h. 192. Lihat juga Imron, Arifin, Kepemimpinan Kyai Kasus Pondok Pesantren Tebuireng, (Malang : Kalimasahada Press, 1993), h. 5-6

${ }^{3}$ Imron, Arifin, Kepemimpinan Kyai : Kasus Pondok Pesantren Tebuireng, (Malang : Kimasahada Press, 1993), h. 
Dalam perkembangannya pondok pesantren tidak sebatas menjalankan pendidikan non formal yang berpusat di masjid, melainkan juga menerapkan sistem pembelajaran formal di madrasah, ini tentunya sesuai dengan empat dasar bagi para kyai (baca tuan guru) dalam pengabdiannya pada masyarakat yaitu "kyai sebagai pengabdi di masjid, kyai sebagai pengabdi di madrasah, kyai sebagai pengabdi di pesantren, dan kiyai sebagai pengabdi di sekolah"4

Dengan diterapkannya pembelajaran di madrasah atau sekolah, maka pola pembelajaran di pondok pesantren selain pembelajaran yang bersifat non formal dengan sejumlah kitabkitab kuning yang diajarkan di dalamnya serta jenis-jenis metode yang diterapkan, juga melalukan pembelajaran formal di kelas dengan tuntutan penerapan metode pembelajaran yang bervariasi dalam upaya mencapai tujuan pembelajaran Pendidikan Agama Islam sesuai materi yang diajarkan oleh masing-masing guru berdasarkan mata pelajaran yang diampunya.

Sejumlah metode dapat diterapkan dalam pembelajaran dalam Pendidikan Agama Islam (Fikih, Aqidah-Akhlak, al-Qur'an-Hadis, Sejarah Kebudayaan Islam dan termasuk Bahasa Arab), di sekolah/madrasah antaranya "(1) metode ceramah, (2) metode tanya jawab, (3) metode demonstrasi, (4) metode eksprimen, (5) metode diskusi, (6) metode sosiodrama dan bermain peran, (7) metode drill (latihan), (8) metode tim teaching (mengajar beregu), (9) metode problem solving (pemecahan masalah), (10) metode resitasi (pemberian tugas), (11) metode kerja kelompok, (12) metode imla' (dekte), dan metode simulasi" ${ }^{5}$. Demikian juga ketika pembelajaran Bahasa Arab antaranya "(1) metode mubadasah (bercakap-cakap), (2) metode muthala'ah (membaca), (3) metode imla' (dekte), (4) metode insya' (mengarang), (5) metode mahfudzat (menghafal), dan (6) metode qawaid (nahu saref)"'.

Memperhatikan kitab-kitab kajian yang diajarkan pada pondok pesantren dengan sistem pembelajaran nonformal yang disertakan terapan sejumlah metode, serta juga pada pembelajaran di madrasah dan atau sekolah dengan tuntutan keterampilan ustadz/guru untuk melalukan terapan metode yang bervariasi berdasarkan jenis-jenis metode yang dapat diterapkan dan sesuai dengan tujuan pembelajaran pada pembelajaran Pendidikan Agama Islam termasuk pembelajaran Bahasa Arab sebagaimana dikemukakan di atas, jika kemudian dihubungkan dengan keberadaan pondok pesanstren dewasa ini (Tahun 2016) ketika penelitian ini dilakukan khususnya pada Pondok Pesantren Al-Aziziyah Kapek Gunungsari Lombok Barat yang keberadaannya sangat-sangat dikenal tidak sebatas dalam taraf regional namun juga nasional, menyebabkan termotivasinya peneliti untuk ingin mengetahui lebih dekat penerapan metode pembelajaran di Pondok Pesantren Al-Aziziyah Kapek Gunungsari Lombok Barat.

\footnotetext{
${ }^{4}$ Horikoshi, H, Kyai dan Perubahan Sosial, (Jakarta : P3M, 1987), h. 116

${ }^{5}$ Ramayulis, Metodologi Pendidikan Agama Islam, Edisi Revisi, (Jakarta : Kalam Mulia, 2010), h. 299-381

6 Tayar Yusuf, H., dan Syaiful Anwar, Metodologi Pengajaran Agama dan Babasa Arab, (Jakarta : Raja Grafindo Persada, 1997), h. 191-207
} 
Motivasi peneleiti ini diperkuat dengan data hasil obervasi awal yang menunjukkan masih kurang bervariasinya penerapan metode berdasarkan tujuan pembelajaran sesuai ranah Bloom (ranah kognitif/pengetahuan/ilmu, ranah afektif/ sikap/iman, dan ranah psikomotor/keterampilan/amal) sesuai konten pembelajaran di Pondok Pesantren AlAziziyah oleh guru-guru bidang studi atau mata pelajaran baik pada pembelajaran formal khususnya pada Madrasah Tsnawiyah Putra-Putri, Madrasah Aliyah Putra-Putri, dan pembelajaran di Madrasah Qur'an wal Hadis. Demikian pula penerapan metode pada pembelajaran non formal dalam mengkaji kitab kuning pada kegiatan ta'limul lail. Sehingga perlu mengkaji secara mendalam tentang adalah mengetahui metode-metode, Langkah penerapan metode, faktor pendukung dan penghambat serta Langkah antisipasi pada pembelajaran formal dan non formal di Pondok Pesantren Al-Aziziyah Kapek Gunungsari Lombok Barat.

Sementara jika memperhatikan keberadaan ustadz/ustadzah atau guru yang mengajar di Pondok Pesantren Al-Aziziyah baik pada pembelajaran formal di Madrasah Tsnawiyah PutraPutri, Madrasah Aliyah Putra-Putri, dan Madrasah Qur'an wal Hadis serta pada pembelajaran non formal (kajian kitab kuning) berjumlah 213 orang yang memiliki jenjang pendidikan S.2 15 orang atau 7,04 \%, yang memiliki jenjang pendidikan S.1 160 orang atau 75,12\%, yang memiliki jenjang pendidikan diploma 2 orang atau $0,94 \%$, dan yang memiliki jenjang pendidikan Sekolah Menengah Atas/Madrasah Aliyah 36 orang atau 16,9\%.

\section{METODE PENELITIAN}

Pendekatan yang digunakan peneliti dalam penelitian ini adalah pendekatan deskriptif kualitatif. Sebab orientasi penelitian yang dilakukan berdasarkan pada gejala atau fenomena yang bersifat alam. Sehingga hasil yang didapatkan adalah data deskriptif atau pemaparan dari suatu peristiwa yang diteliti. Metode penelitian kualitatif sebagai "prosedur penelitian yang menghasilkan data deskriptif berupa kata-kata tertulis atau lisan dari orang-orang dan perilaku yang dapat diamati"7. Pendekatan kualitatif diterapkan dalam kegiatan penelitian menurut Lexy J. Moleong, jika "Penelitian yang bermaksud untuk memahami fenomena tentang apa yang dialami oleh subjek penelitian misalnya perilaku, persepsi, motivasi, tindakan dll, secara holistik dan dengan cara deskripsi dalam bentuk kata-kata dan bahasa, pada suatu konteks khusus yang alamiah dan dengan memanfaatkan berbagai metode alamiah". ${ }^{8}$

Dalam penelitian kualitatif kehadiran peneliti di lokasi penelitian adalah sebagai instrumen kunci dalam upaya menemukan data melalui pengamatan atau observasi secara langsung atau observasi partisipasi dan observasi nonpartisipasi. Peneliti sebagai instrumen kunci sesuai pernyataan bahwa "metode penelitian yang berdasarkan pada filsafat

\footnotetext{
${ }^{7}$ Moleong, Lexy J., Metodologi Penelitian Kualitatif, (Bandung: PT Remaja Rosdakarya, 2010), h. 4.

8 Ibidi., h. 6.
} 
postpositivisme, digunakan untuk meneliti pada kondisi obyek yang alamiah dimana peneliti adalah sebagai instrument kunci..."9.

Adapun tehnik pengumpulan data yang digunakan dalam penelitian ini dapat peneliti jabarkan sebagai berikut;

1. Sumber data dalam penelitian ini dengan cara peneliti memilih informan yang dapat membantu untuk mendapatkan data yaitu: person atau orang adalah sumber data yaitu guru Pendidikan Agama Islam yang mengajar di Pondok Pesantren Al-Aziziyah Kapek Gunungsari Lombok Barat baik pada pembelajaran formal maupun non formal.

2. Prosedur pengumpulan pada penelitian ini menggunakan dua metode, yaitu pertama metode observasi tidak langsung. Kedua, metode interview/wawancara yang diartikan sebagai "percakapan dengan maksud tertentu, percakapan itu dilakukan oleh dua pihak, yaitu pewawancara (interviewer) yang mengajukan pertanyaan dan terwawancara (interviewee) yang memberikan jawaban atas pertanyaan itu"10. Metode ini terdiri dari wawancara berstruktur dan tak terstruktur lebih bersifat informal"11. Dalam penelitian ini peneliti menggunakan wawancara tak ter struktur yaitu pada saat melakukan wawancara tidak menetapkan terlebih dahulu pertanyaan-pertanyaan yang akan dipertanyakan, dengan tujuan untuk menyegarkan suasana dialog supaya tidak kaku, dan untuk pengembangan pertanyaan-pertanyaan sesuai kebutuhan peneliti. Ketiga, metode dokumentasi merupakan "cara mencari data mengenai hal-hal atau variabel yang berupa catatan, transkrip, buku, surat kabar, majalah, prasasti, notulen rapat, lengger, agenda, dan sebagainya"12.

3. Analisa data dalam penelitian menggunakan analisis Reduction (Reduksi Data) yang berarti merangkum, memilih hal-hal yang pokok, memfokuskan pada hal-hal yang penting, dicari tema dan pokoknya dan membuang yang tidak perlu. Display (Penyajian Data) yang bentuknya bisa uraian singkat, bagan, hubungan antar kategori dansejenisnya, (3) Conclusion Drawing atau Verification (Mengambil Kesimpulan dan Verifikasi13

4. Kredibilitas data dalam penelitian ini dengan cara; Pertama, mencari secara konsisten interpretasi dengan berbagai cara dengan proses analisis yang konstan dan tentatif'14. Ketekunan pengamatan bermaksud "menemukan ciri-ciri dan unsur-unsur dalam situasi yang sangat releven dengan persoalan atau isu yang sedang dicari dan kemudian memusatkan diri pada hal-hal tersebut secara rinci. ${ }^{15}$ Kedua menggunakan Triagulasi, yang

\footnotetext{
${ }^{9}$ Sugiyono, Metode Penelitian Pendidikan..., h. 15

10 Moleong, Lexy J., Metodologi..., h. 186

11 Zuhriah, Nurul, Metodologi Penelitian Sosial ..., h. 180-181

12 Suharsimi Arikunto, Prosedur Penelitian Suatu Pendekatan Praktik, Edisi Revisi VI, Jakarta : Rineka Cipta, 2006), h. 231

13 Ibid., h. 338-345

${ }^{14}$ Lexy J. Moleong, Metodologi..., h. 327

15 Ibid., h. 330
} 
merupakan "teknik pemeriksaan keabsahan data yang memanfaatkan sesuatu yang lain"16. Dari empat jenis trianggulasi yaitu "penggunaan sumber, metode, penyidik, dan teori"17, dalam penelitian ini menggunakan trianggulasi sumber di samping trianggulasi metode dan trianggulasi data.

\section{TEMUAN DAN PEMBAHASAN}

\section{Metode Pembelajaran di Pondok Pesantren}

Penerapan salah satu jenis metode dalam kegiatan pembelajaran hendaknya sesuai dengan tujuan dan materi yang diajarkan untuk kemudian diterapkan jenis alat evaluasi untuk mengetahui tingkat keberhasilan guru dalam mengajar dan keberhasilan siswa dalam belajar. Hal ini mengingat pembelajaran pada dasarnya adalah "rangkaian kegiatan yang direncanakan lebih dahulu oleh penyelenggara pendidikan atau oleh pengajar dan terarah pada hasil belajar tertentu"18. Atau pembelajaran adalah "suatu kombinasi yang tersusun, meliputi unsur-unsur manusiawi, material, fasilitas, perlengkapan, dan prosedur yang saling mempengaruhi untuk mencapai tujuan pembelajaran"19. Pembelajaran juga diartikan "setiap kegiatan yang dirancang untuk membantu seseorang mempelajari suatu kemampuan dan atau nilai yang baru"20. Bahkan pembelajaran atau proses belajar mengajar juga diartikan "serangkaian aktivitas yang disepakati dan dilakukan guru-murid untuk mencapai tujuan pendidikan secara optimal"21.

Memperhatikan pengertian pembelajaran atau proses belajar mengajar di atas dapat ditemukan kata kunci yang terdapat di dalamnya dimana pembelajaran adalah kegiatan yang direncanakan oleh guru atau pengajar untuk mencapai tujuan pembelajaran. Pembelajaran sebagai kegiatan yang secara sengaja direncanakan oleh guru ketika berinteraksi dengan siswa dalam upaya mencapai tujuan pembelajaran itu sendiri dalam terapannya melalukan serangkaian komponen pembeljaran yang saling mendukung satu sama lain, salah satunya adalah komponen metode pembelajaran yang merupakan "cara yang digunakan oleh pendidik dalam mengadakan hubungan dengan peserta didik pada saat berlangsungnya proses pembelajaran"22.

${ }^{16}$ Ibid., h. 331

${ }^{16}$ Ibid., h. 330-331

${ }^{17}$ Ibid., h. 330

18 Suparman, M. Atwi, Desain Instruksional Modern: Panduan Para Pengajar \& Inovator Pendidikan, (Jakarta : Erlangga, 2012), h. 10

${ }^{19}$ Aqib, Zainal, Profesionalisme Guru dalam Pembelajaran, (Surabaya: Insan Cendekia, 2002), h. 41

${ }^{20}$ Sagala, Syaiful, Konsep dan Makna Pembelajaran: Untuk. Membantu Memecabkan Problematika Belajar dan Mengajar, (Bandung : Alfabeta, 2012), h. 61

${ }^{21}$ Fathurrohman, Pupuh dan Sutikno, M. Sobry, Strategi Belajar Mengajar: Strategi Mewrijudkan Pembelajaran Bermakna Melalui Penanaman Konsep Umum \& Konsep Islami, (Bandung: Refika Aditama, 2007), h. 10

${ }^{22}$ Ramayulis, Metodologi Pendidikan Agama ..., h. 3 
Keberadaan metode pada kegiatan pembelajaran dapat diterapkan di kelas non formal (asrama, masjid, langgar dan sejenisnya) dan dapat pula diterapkan di kelas formal (sekolah atau madrasah) dimana pada pembelajaran non formal beberapa metode yang diterapkan antaranya :

1. Metode Wetonan

Metode wetonan atau bandongan yang terapannya dilakukan dengan cara "kyai membaca sesuatu kitab dalam waktu tertentu dan santri membawa kitab yang sama, kemudian santri mendengarkan dan menyimak tentang bacaan kyai tersebut"23. Santri ketika ustadz/ ustadzah atau guru menerapkan metode ini diberikan kebebasan untuk mengikuti atau tidak mengikuti pembelajaran. Absensi santri tidak dilakukan ketika pembelajaran berlangsung dan tidak menggunakan istilah kenaikan kelas. Lama belajar santri tidak tergantung pada lama tahun belajar, akan tetapi ditentukan oleh cepat tidaknya santri manamatkan kitabnya. Bagi santri yang lebih cepat menamatkan kitabnya, maka yang bersangkutan boleh meneruskan ke kitab yang lebih tinggi atau mempelajari kitab yang lain.

2. Metode Sorogan

Metode sorogan, yang diakui merupakan "metode yang paling sulit dari keseluruhan metode pendidikan Islam tradisional, sebab dalam penerapan metode sorogan dituntut kesabaran, kerajinan, kataatan dan disiplin pribadi dari murid"24. Metode ini dalam penerapannya dilakukan dengan cara santri mengajukan kitab yang akan dibaca kepada kyai, kemudian ketika santri membaca kitab terdapat kesalahan, maka kesalahan tersebut disempurnakan langsung oleh kyai. Pembelajaran kitab dengan penerapan metode sorogan dilakukan untuk santri yang permulaan belajar atau kepada santri-santri khusus yang dianggap pandai dan diharapkan dikemudian hari menjadi seorang 'alim.

3. Metode Muhawarah

Metode muhawarah atau muhadasah, merupakan metode untuk "melatih santri bercakap-cakap dengan bahasa Arab yang diwajibkan oleh pesantren kepada para santri selama mereka tinggal di pondok"25. Penerapan metode muhawarah atau muhadasah dibeberapa pesantren tidak diwajibkan dilakukan setiap hari, ada menerapkan satu atau dua kali dalam seminggu yang digabungkan dengan latihan muhadlarah atau kitabah yang bertujuan melatih ketrampilan santri berpidato.

23 Syis, Z.A., et.al., Standarisasi Pengajaran Agama di Pondok Pesantren, Jakarta: Dirdjen Bimbaga Islam Depaertemen Agama Republik Indonesia, 1984), h. 19

${ }^{24}$ Dhofir, Zamahsari., Tradisi Pesantren: Studi tentang Pandangan Hidup Kyai, (Jakarta: LP3ES, 1984), h. 28

${ }_{25}$ Imron, Arifin, Kepemimpinan Kyai ..., h. 39 
4. Metode Mudzakarah

Metode mudzakarah merupakan "suatu pertemuan ilmiah yang secara spesifik membahas masalah diniyah seperti ibadah dan akidah serta masalah agama pada umumnya"26. Dalam penerapannya metode mudzakarah dibedakan menjadi menjadi tiga tingkatan kegiatan, yaitu tingkatan pertama mudzakarah yang dilakukan oleh sesama santri untuk membahas suatu masalah dengan tujuan melatih para santri agar terlatih dalam memecahkan persoalan dengan menggunakan kitab-kitab yang tersedia. Salah seorang santri ditunjuk sebagai juru biacara untuk menyampaikan kesimpulan dari masalah yang didiskusikan. Tingkatan kedua mudzakarah yang dipimpin oleh kyai, dimana pada tingkatan ini hasil mudzakarah para santri diajukan untuk dibahas dan dinilai oleh kyai. Biasanya dalam mudzakarh tingkat kedua ini berisi tanya jawab dengan mayoritas menggunakan bahasa Arab sebagai bahasa komunikasi. Tingkat ketiga mudzakarah antar kyai. Ini biasanya menggunakan kitab-kitab yang tersedia untuk menyelesaikan suatu masalah yang penting. Mudzakarah ini juga dilakukan untuk memper dalam pengetahuan agama para kyai, dan

5. Metode Majlis Ta'lim

Metode majlis ta'lim merupakan "suatu media penyampaian ajaran Islam yang bersifat umum dan terbuka"27. Dalam penerapan metode ini peserta pembelajaran atau disebut dengan jama'ah terdiri dari berbagai lapisan yang memiliki latar belakang pengetahuan bermacam-macam dan tidak dibatasi oleh tingkat usia maupun perbedaan kelamin. Penerapan metode pada kegiatan ta'lim di pondok pesantren dilakukan pada waktu-waktu tertentu, ada yang seminggu sekali atau sebulan sekali. Terkait dengan materi yang disampaikan dengan penerapan metode ini "umumnya berisi nasehat-nasehat keagamaan yang bersifat amar ma'ruf nahi munkar. Ada kalanya materi diambil dari kitabkitab tertentu seperti tafsir Qur'an dan Hadits"28.

Sedangkan pada pembelajaran formal (di sekolah atau madrasah) di antara metode yang dapat diterapkan yaitu :

1. Metode Ceramah

Metode Ceramah merupakan "cara penyajian atau penyampaian informasi melalui penerangan dan penuturan secara lisan oleh pendidik terhadap peserta didiknya" 29 . Jika mencermati ayat-ayat al-Qur'an yang disampaikan kepada Nabi Muhammad saw. ternyata banyak disampaikan dalam bentuk ceramah.

${ }^{26}$ Ibid., h. 39

${ }^{27}$ Ibid., h. 39

${ }^{28}$ Sunyoto, A., Ajaran Tasanuf dan Pembinaan Sikap Hidup Santri Pesantren Nurul Haq Surabaya : Studi Kasus, (Malang : FPS IKIP, 1990), h. 75

${ }^{29}$ Ramayulis, Metodologi Pendidikan Agama ..., h. 299 
Metode ini akan dapat diterapkan dalam kegiatan pembelajaran oleh ustadz/ustadzah atau guru jika (1) jumlah peserta didik terlampau banyak sehingga sulit menyampai kan metode lain, (2) bahan yang disampaikan merupakan topik baru yang mengandung informasi, penjelasan atau uraian (3) tidak ditemui bahan yang disampaikan itu dalam buku yang akan dipergunakan oleh peserta didik sebagai buku pedoman (4) pendidik seorang pembicara yang mahir dan bersemangat dan dapat menarik serta merangsang perhatian peserta didik (5) pendidik menyimpulkan dari pokok-pokok yang penting dari ceramah yang diberikan, sehingga peserta didik-peserta didik dapat melihat hubungan antara pokok-pokok masalah itu, (6) bahan yang hatus diajarkan banyak sekali sedangkan waktu amat terbatas, (7) dalam memberikan gambaran/ilistrasi terhadap bahan pelajaran dan kata-kata tertentu, metode ceramah yang tepat dipergunakan, (8) untuk menumbuhkan serta menanamkan apresiasi/penghayatan terhadap isi sajak, puisi, watak orang, dengan metode ceramah juga dapat dilaksanakan, dan (9) apabila tidak ada alat-alat yang lain kecuali bahasa lisan. ${ }^{30}$

2. Metode Tanya Jawab

Metode tanya jawab adalah "suatu cara menyajikan materi pelajaran dengan jalan guru mengajukan suatu pertanyaan-pertanyaan kepada siswa untuk dijawab, bisa pula diatur pertanyaan-pertanyaan diajukan oleh siswa lainnya"31. Penerapan metode ini dalam al-Qur'an banyak dicontohhkan oleh Allah swt. dalam menyampaikan firman-Nya, diantaranya dalam surat Ar-Rahman (55) ayat 46-51, sebagai berikut :

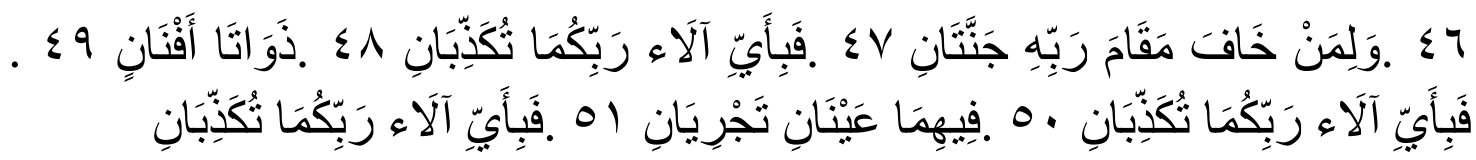

"(46) Dan bagi siapa yang takut akan saat menghadap Tuhannya ada dua syurga (surga untuk. manusia dan surga untuk jin, dan ada juga mufassir yang berpendapat surga dunia dan surga akbirat), (47) maka nikmat Tuhanmu yang manakah yang kamu dustakan?, (48) kedua syurga itu mempunyai aneka pepohonan dan buab-buahan, (49) maka nikemat Tubanmu yang manakah yang kamu dustakan?, (50) Di dalam kedua syurga itu ada dua buah mata air yang memancar, (51) maka nikmat Tubanmu yang manakah yang kamu dustakan?. "32

Metode ini dapat diterapkan bila : (a) guru atau ustadz bermaksud mengetahui penguasaan materi pelajaran yang telah dipelajari, baik dari pelajaran yang lalu untuk meneruskan pelajaran berikutnya (yang baru), maupun yang sudah ditugaskan untuk dipelajari (b) guru atau ustadz bermaksud menarik dan memusatkan perhatian murid atau santri dalam mengikuti ceramahnya tentang suatu materi pelajaran tertentu, (c) untuk melakukan pengecekan perhatian murid atau santri pada waktu mendengarkan ceramah,

\footnotetext{
30 Usman, Basyiruddin, Metodology Pengajaran Agama Islam, (Padang : ININ IB Press, 1999), h. 40

31 Tayar, Yusuf, H., dan Anwar, Syaiful, Metodologi Pengajaran Agama ..., h. 61

32 Kementerian Agama RI., Mushaf Al-Qur'an ..., h. 533
} 
mengenai suatu materi pelajaran dari guru atau ustadz, dan (d) guru atau ustadz bermaksud mengarahkan atau memimpin pemikiran atau pengamatan murid atau santri. ${ }^{33}$

3. Metode Demonstarsi

Metode demontrasi merupakan "cara yang digunakan dalam penyajian pelajaran dengan cara meragakan bagaimana membuat, mempergunakan serta memperaktikkan suatu benda atau alat baik asli maupun tiruan, atau bagaimana mengerjakan sesuatu perbuatan atau tindakan yang mana dalam meragakan disertai dengan penjelasan lisan"34.

Kelebihan metode ini adalah (1) keaktifan peserta didik akan ber tambah, lebihlebih kalau peserta didik diikut sertakan, (2) pengalaman peserta didik bertambah karena peserta didik turut membantu pelaksanaan suatu demontrasi sehingga ia menerima pengalaman yang bisa mengembang kan kecakapannya (3) pelajaran yang diberikan lebih tahan lama, karena dalam suatu demontrasi peserta didik bukan saja mendengar suatu uraian yang diberikan oleh pendidik tetapi juga memperhatikannya bahkan turut serta dalam pelaksanaan suatu demontrasi, (4) pengertian lebih cepat dicapai, karena peserta didik dalam menanggapi suatu proses adalah dengan menggunakan alat pendengar, penglihat, dan bahkan dengan perbuatannya sehingga memudahkan pemahaman peserta didik dan meng hilangkan sifat verbalisme dalam belajar, (5) perhatian peserta didik dapat dipusatkan dan titik yang dianggap penting oleh pendidik dapat diamati oleh peserta didik seperlu nya, sebab peserta didik lebih banyak diajak mengamati proses yang sedang berlangsung dari pada hanya semata-mata mendengar saja, (6) mengurangi kesalahan-kesalahan paham yang diberikan melalui penjelasan lisan, sebab melalui demontrasi di samping peserta didik mendapatkan penjelasan dengan lisan juga dapat memberi kan gambaran konkrit, (7) beberapa masalah yang menimbulkan pertanyaan atau masalah dalam diri peserta didik dapat terjawab pada waktu peserta didik mengamati proses demontrasi, dan (8) menghindari "coba-coba dan gagal” yang banyak memakan waktu belajar, di samping praktis dan fungsional, khususnya bagi peserta didik yang ingin berusaha mengamati secara lengkap dan teliti atau jalannya sesuatu.

Kelemahannya (1) metode ini membutuhkan kemampuan yang optimal dari pendidik untuk itu perlu persiapan yang matang, dan (2) sulit dilaksanakan kalau tidak ditunjang oleh tempat, waktu dan peralatan yang cukup. ${ }^{35}$

4. Metode Drill

Metode drill (latihan) atau disebut juga dengan latihan sikap, merupa kan "cara menyajikan bahan pelajaran dengan jalan/cara melatih siswa agar menguasai pelajaran

${ }^{33}$ Nawawi, Hadari, Pendidikan dalam Islam, (Surabaya : Al Ikhlas), 1993, h. 258-259 dan 261

34 Syah, Darwyn, Perencanaan Sistem Pengajaran Pendidikan Agama Islam, (Jakarta : Gaung Persada Press, 2007), h. 152

${ }^{35}$ Ramayulis, Metodologi Pendidikan Agama ..., h.314 
dan terampil dalam melaksanakan tugas latihan yang diberikan"36. Dalam Al-Qur'an metode ini banyak dicontohkan dalam bentuk terapannya antaranya sebagaimana dinyatakan Allah swt. dalam surat al-Hijir (15) ayat 87 :

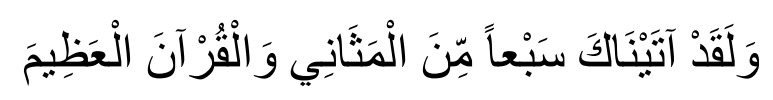

'Dan sungguh, Kami telah berikan kepadamu tujuh (ayat) yang (dibaca) berulang-ulang (surat al-Fatihab yang terdiri dari tujuh ayat, sebagian mufassir mengatakan tujuh surah yang panjang, yaitu al-Baqarah, 'Ali Imran, al-Maidah, an-Nisa', al-'A'raf, al-'An'am, dan al-Anfal atau at-Taubah) dan Al Quran yang agung” (Q.S. Aj-Hijir : 87).37

Kelebihannya (1) dalam waktu yang tidak terlalu lama siswa dapat memperoleh pengetahuan dan keterampilan yang diperlukan, (2) siswa memperoleh pengetahuan praktis dan siap pakai, mahir dan lanca,(3) menumbuhkan kebiasaan belajar secara kontinu dan disiplin diri, melatih diri, belajar mandiri (4) Pada pelajaran agama dengan melalui metode latihan siap ini anak didik menjadi terbiasa dan menumbuhkan semangat untuk beramal kepada Allah.

Kekurangannya (1) dapat menjadi penghambat bakat dan inisiatif siswa sebab melalui cara/metode ini, berarti para siswa dibawa kepada konformitas dan diarahkan kepada uniformitas, (2) siswa dapat statis dalam penyesuaian dengan situasi lingkungan dan terpaku dengan petunjuk-petunjuk praktis tertentu, serta inisiatif siswa untuk mengembangkan sesuatu yang baru menjadi terikat. Hal ini berarti bertentangan dengan prinsip-prinsip teori belajar, (3) membentuk kebiasaan yang kaku yang bersifat mekanis dan rutinitas. Kurang memperhatikan aspek intelektual anak didik, (4) pengajaran cenderung bersifat verbalisme, (5) dalam melaksanakan metode ini memakan waktu/proses yang cukup banyak/lama (6) dalam pelajaran agama memerlukan ketelatenan/ketekunan serta kesabaran dari pihak guru maupun dari siswa sendiri. ${ }^{38}$

5. Metode Problem Solving

Metode probel solving (pemecahan masalah) adalah "penyajian bahan ajar oleh guru dengan merangsang anak berpikir secara sistematis dengan menghadapkan siswa kepada beberapa masalah yang harus dipecahkan". ${ }^{39}$

Metode ini memilii sisi positif, yaitu (1) memungkinkan relevansi antara dunia pendidikan dengan dunia kerja, (2) membiasakan siswa terampil menghadapi dan memecahkan masalah (3) merangsang proses berfikir kreatif dan menyeluruh. Sisi negatifnya (1) sulit menentukan tingkat masalah yang disesuaikan dengan tingkat pemahaman dan perkembangan siswa, (2) memakan waktu yang lama dan menyita waktu

\footnotetext{
36 Tayar, Yusuf, H., dan Anwar, Syaiful, Metodologi Pengajaran Agama ... ,h. 65

${ }^{37}$ Kementerian Agama RI., Mushaf Al-Qur'an ... Ibid, h. 266

38 Tayar, Yusuf, H., dan Syaiful Anwar, Metodologi Pengajaran Agama ..., h. 66

39 Syah, Darwyn, Perencanaan Sistem Pengajaran ..., h. 155
} 
yang diperguna kan untuk jam pelajaran lain, (3) sulit mengubah pola belajar siswa dari menjadikan guru sebagai sumber belajar utama kepada belajar dengan berpikir yang mem butuhkan lebih banyak lagi sumber belajar. ${ }^{40}$

6. Metode Resitasi

Metode resitasi (pemberian tugas) merupakan "cara mengajar di mana seorang pendidik memberikan tugas-tugas tertentu kepada peserta didik, sedangkan hasil tersebut diperiksa oleh pendidik dan peserta didik mempertanggung jawabkannya"41.

Kelebihannya (1) peserta didik belajar membiasakan untuk mengambil inisitaif sendiri dalam segala tugas yang diberikan, (2) meringankan tugas pendidikan yang diberikan, (3) dapat mempertebal rasa tanggung jawab, karena hasil-hasil yang dikerjakan dipertanggung jawabkan dihadapan pendidik, (4) memupuk anak mereka dapat berdiri sendiri tanpa mengharap kan bantuan orang lain, (5) mendorong peserta didik supaya suka berlomba-lomba untuk mencapai sukses, (6) hasil pelajaran akan tahan lama karena pelajaran sesuai dengan minat peserta didik, (7) dapat memperdalam pengertian dan menambah keaktipan dan kecakapan peserta didik, (8) waktu yang dipergunakan tidak terbatas sampai pada jam-jam sekolah. Sedangkan kelemahannya (1) peserta didik yang terlalu bodoh sukar sekali belajar, (2) kemungkinan tugas yang diberikan tapi dikerjakan oleh orang lain, (3) kadang-kadang peserta didik menyalin atau meniru pekerjaan temannya sehingga pengalamannya sendiri tidak ada, (4) kadang-kadang pembahasan nya kurang sempurna, (5) bila tugas terlalu sering dilakukan oleh peserta didik akan menyebabkan (a) terganggunya kesehatan peserta didik, karena mereka kembali dari sekolah selalu melakukan tugas, sehingga waktu bermain tidak ada, (b) menyebabkan peserta didik asal mengerjakan saja karena mereka menganggap tugas-tugas tersebut membosankan, (6) mencari tugas yang sesuai dengan kemampuan setiap individu sulit, jalan pelajaran lambat dan memakan waktu yang lama, (7) kalau peserta didik terlalu banyak kadang-kadang pendidik tidak sanggup memeriksa tugas-tugas peserta didik tersebut. $^{42}$

7. Metode Diskusi

Metode diskusi adalah "metode pembelajaran yang menghadapkan siswa pada suatu permasalahan dengan tujuan untuk memecahkan suatu permasalahan, menjawab pertanyaan, menambah dan memahami pengetahuan siswa, serta untuk membuat suatu keputusan"43.

\footnotetext{
40 Ibid., h. 156

${ }^{41}$ Ramayulis, Metodologi Pendidikan Agama ..., h.361

42 Sudirman.at.al., Ilmu Pendidikan, (Bandung : Remaja Karya), 1987, h. 145

${ }^{43}$ Sanjaya, Wina, Strategi Pembelajaran Berorientasi Standar Proses Pendidikan, Jakarta : Kencana Prenadamedia Group, 2006), h. 154
} 
Kelebihannya (1) etode diskusi dapat merangsang siswa untuk lebih kreatif khususnya dalam memberikan gagasan dan ide-ide, (2) dapat melatih untuk membiasakan diri bertukar pikiran dalam mengatasi setiap permasalahan, (3) dapat melatih siswa untuk dapat mengemukakan pendapat atau gagasan secara verbal. Di samping juga bisa melatih siswa untuk menghargai pendapat orang lain. Sedangkan kelemahannya (1) sering terjadi pembicaraan dalam diskusi dikuasai oleh 2 atau 3 orang siswa yang memiliki keterampilan berbicara, (2) kadan-kadang pembahasan dalam diskusi meluas, sehingga kesimpulan menjadu kabur, (3) memerlukan waktu yang cukup panjang, yang kadang-kadang tidak sesuai dengan cara yang direncanakan, (4) dalam diskusi sering terjadi perbedaan pendapat yang bersifat emosional yang tidak terkontrol, akibatnya kadang-kadang ada pihak yang merasa tersinggung, sehingga dapat mengganggu iklim pembelajaran. ${ }^{44}$

Bagi peneliti sejumlah jenis-jenis metode pembelajaran di atas, dapat dijadikan refrensi ketika mengkaji pengetahuan dan keterampilan ustadz/ustadzah atau guru dalam menerapkan setiap jenis metode dalam pembelajaran Pendidikan Agama Islam khususnya di Pondok Pesantren Al-Aziziyah Kapek Gunungsari Lombok Barat.

\section{SIMPULAN}

Penelitian menghasilkan data berupa diterapkan empat metode dalam pembelajaran formal di Madrasah Tsnawiyah Putra-Putri, Madrasah Aliyah Putra-Putri, dan Madrasah Qur'an wal Hadis Pondok Pesantren Al-Aziziyah pada pembelajaran Pendidikan Agama Islam (Fikih, Aqidah-Akhlak, Al-Qur'an-Hadis dan juga Bahasa Arab) yaitu (a) metode ceramah, (b) metode tanya jawab, (c) metode penugasan/resitasi, dan (d) metode latihan/drill. Sedangkan pada pembelajaran non formal ketika kajian diterapkan metode bandongan/wetonan dan sorogan. Llangkah terapanan metode di atas belum diterapkan dengan sempurna, dan bervariasi. Langkah terapan dalam kegiatan pembelajaran, didominasi oleh penerapan metode ceramah dari 80 menit (60 menit penerapan metode ceramah, 20 menit penerapan metode lainnya yaitu metode tanya jawab dan penugasan), pada kegiatan pembelajaran di Madrasah Tsnawiyah, dan 90 menit (70 menit penerapan metode ceramah, 20 menit penerapan metode lainnya yaitu tanya jawab dan penugasan).

Sedangkan faktor pendukung penerapan metode adalah karena terbiasa menggunakan metode-metode tersebut, meskipun secara teoritis masih belum sempurna. Sementara faktor penghambat (a) kurang mengkaji literatur konsep pendidikan/pengajaran, (b) kurang trampil dalam penerapan metode, dan (c) tidak didukung dengan ketersediaan RPP, karena kurang trampil dalam merancangnya.

\footnotetext{
${ }^{44}$ Sanjaya, Wina, Strategi Pembelajaran Berorientasi ..., h. 156
} 
Soluasi mengatasi kesulitan, (a) ketersediaan buku-buku refrensi tentang penddikan/pembelajaran, (b) diperlukan latihan atau workhsop baik yang dilakukan pemerintah maupun oleh Kelompok Kerja Madrasah (KKM). Paparan data ini sekalgus juga merupakan kesimpulan yang diperoleh dalam penelitian ini.

\section{DAFTAR PUSTAKA}

Aqib, Z. Profesionalisme Guru dalam Pembelajaran. Surabaya: Insan Cendekia, 2002.

Arikunto, S. Prosedur Penelitian Suatu Pendekatan Praktik. Jakarta: Rineka Cipta, 2006

Departemen Agama RI. Al-Qur'an dan Terjemahannya. Jakarta: Yayasan Penyelenggara PenterjemahAl-Qur'an Departemen Agama RI, 2004.

Dhofir, Z. Tradisi Pesantren: Studi tentang Pandangan Hidup Kyai. Jakarta: LP3ES, 1984.

Fathurrohman, P. dan M. Sobry Sutikno. Strategi Belajar Mengajar: Strategi Mewujudkan Pembelajaran Bermakna Melalui Penanaman Konsep Umum \& Konsep Islami. Bandung: Refika Aditama, 2007.

Ginting, A. Esensi Praktis Belajar \& Pembelajaran: Disiapkan untuk Pendidikan Profesi dan Sertifikasi Guru-Dosen. Bandung: Humaniora, 2007

Horikoshi. Kyai dan Perubahan Sosial. Jakarta: P3M, 1987.

Hamalik, O. Proses Belajar Mengajar, Jakarta: Bumi Aksara, 2001.

Hassan, A. Tarjamah Bulughul Maram Ibnu Hajar Al-'Asqalani : Terjemahan Beserta Keterangannya dengan Muqaddimah Ilmu Hadits dan Ushul Fiqih. Bandung: Diponegoro, 2006.

Imron, A. Kepemimpinan Kyai: Kasus Pondok Pesantren Tebuireng. Malang: Kimasahada Press, 1993.

Kementerian Agama RI. Mushaf Al-Qur'an: Al-Qur'an Hafalan, Terjemah, Penjelasan Tematik Ayat. Jakarta: Yayasan Penyelenggara Penerjemah/Penafsiran Al-Qur'an Revisi Terjemah oleh Lajnah Pentashih Mushaf Al-Qur'an Kemneterian Agama Republik Indonesia, 2012.

Mastuhu. Dinamika Sistem Pendidikan Pesantren: Suatu Kajian Tentang Unsur dan Nilai Sistem Pendidikan Pesantren. Jakarta: Indonesia-Netherlands Cooperation in Islamic Studies/INIS, 1994.

Moleong, L. J. Metodologi Penelitian Kualitatif. Bandung: PT Remaja Rosdakarya, 2010.

Nawawi, H. Pendidikan dalam Islam. Surabaya: Al Ikhlas, 1993.

Purwanto. Evaluasi Hasil Belajar. Yoyakarta: Pustaka Pelajar, 2008.

Ramayulis. Metodologi Pendidikan Agama Islam. Jakarta: Kalam Mulia, 2010. 
H. M. Natsir, Sistem Pembelajaran di Pondok Pesantren...

Sagala, S. Konsep dan Makna Pembelajaran: Untuk Membantu Memecabkan Problematika Belajar dan Mengajar. Bandung: Alfabeta, 2012.

Sanjaya, W. Strategi Pembelajaran Berorientasi Standar Proses Pendidikan. Jakarta: Kencana Prenadamedia Group, 2006.

Sudirman.at.al. Ilmu Pendidikan. Bandung: Remaja Karya, 1987.

Sudjana, N. Penilaian Hasil Proses Belajar Mengajar. Bandung: Remaja Rosdakarya, 2009.

Sugiyono. Metode Penelitian Pendidikan Pendekatan Kuantitatif, Kualitatif dan R\&D. Bandung: Alfabeta, 2010.

Sunyoto, A. Ajaran Tasawuf dan Pembinaan Sikap Hidup Santri Pesantren Nurul Haq Surabaya: Studi Kasus. Malang: FPS IKIP, 1990.

Suparman, M. A. Desain Instruksional Modern: Panduan Para Pengajar \& Inovator Pendidikan. Jakarta: Erlangga, 2012.

Syah, D. Perencanaan Sistem Pengajaran Pendidikan Agama Islam. Jakarta: Gaung Persada Press, 2007.

Syis, Z.A. et.al. Standarisasi Pengajaran Agama di Pondok Pesantren. Jakarta: Dirdjen Bimbaga Islam Depaertemen Agama Republik Indonesia, 1984.

Tafsir, A. Ilmu Pendidikan dalam Perspektif Islam. Bandung: Remaja Rosdakarya, 1992.

Tayar, Y. dan Syaiful Anwar. Metodologi Pengajaran Agama dan Bahasa Arab. Jakarta: Rajaq Grafindo Persada, 1997.

Usman, B. Metodology Pengajaran Agama Islam. Padang: ININ IB Press, 1999.

Usman, M. U. Menjadi Guru Profesional. Bandung: Remaja Rosdakarya, 1995.

Widoyoko, S. E. P. Evaluasi Program Pembelajaran: Panduan Praktis bagi Pendidik dan Calon Pendidik. Yogyakarta: Pustaka Pelajar, 2009.

Zuhriah, N. Metodologi Penelitian Sosial dan Pendidikan Teori-Aplikasi. Jakarta: Bumi Aksara, 2009. 